\title{
AN ARTISTIC, MYTHOLOGICAL AND DOCUMENTARY STUDY OF THE ATARGATIS PANEL FROM ET-TANNUR, JORDAN
}

\begin{abstract}
Summary: In 1937 and 1938, a group of high-relief and round statues were uncovered during the joint expedition of the American School of Oriental Research in Jerusalem and the Department of Antiquities in Palestine at the Khirbet et-Tannur Temple, located in Jordan. This expedition was headed by Nelson Glueck (Figs 1,2). The statues uncovered are important in that they offer considerable information about Nabataean art and religion. This paper concentrates on one of the high-relief statues, called the Atargatis Panel by its excavator, Glueck. It was chosen as a case study for its availability in Amman, Jordan. The other Atargatis statues found at the site are now in the Cincinnati Art Museum in the United States of America. This paper also examines the Nabataean religious beliefs concerning Atargatis and her fertility cult, in addition to the art style of the statue. Furthermore, the digital 3D imaging documentation of the Atargatis statue at The Jordan Museum is presented. Dense image matching algorithms presented a flexible, cost-effective approach for this important work. These images not only provide geometric information but also show the surface textures of the depicted objects. This is especially important for the production of virtual 3D models used as a tool for documentary, educational and promotional purposes.
\end{abstract}

Key words: art history, Nabataean sculpture, Khirbet et-Tannur, Atargatis, documentation, 3D imaging, conservation

\section{INTRODUCTION}

After the end of Nelson Glueck's excavation at the Khirbet et-Tannur site, a significant number of Nabataean sculptures, architectural fragments, pottery shards and other archaeological items were presented to the Cincinnati Art Museum. ${ }^{1}$ The remainders of

${ }^{1}$ Freeman, R.: Nabataean Sculpture in the Cincinnati Art Museum. American Journal of Archaeology 45.3 (1941) 337-341; MCKENZIE, J. ET AL.: The Nabataean Temple at Khirbet et-Tannur, Jordan: Final Report on Nelson Glueck's 1937 Excavation [Annual of the American Schools of Oriental Research]. Boston, MA 2013, 67-68. 
the statues left in Jordan are now displayed in The Citadel Archaeological Museum and The Jordan Museum in Amman's city center. The Atargatis Panel is an impressive and beautiful statue and may have been left in Jordan due to its large size and heavy weight.

As a result of natural and human forces, the temple in which the Panel was found has collapsed. It remained in that state from the Roman Period until the time of the excavations in 1937. In addition to removing the archaeological finds now housed at

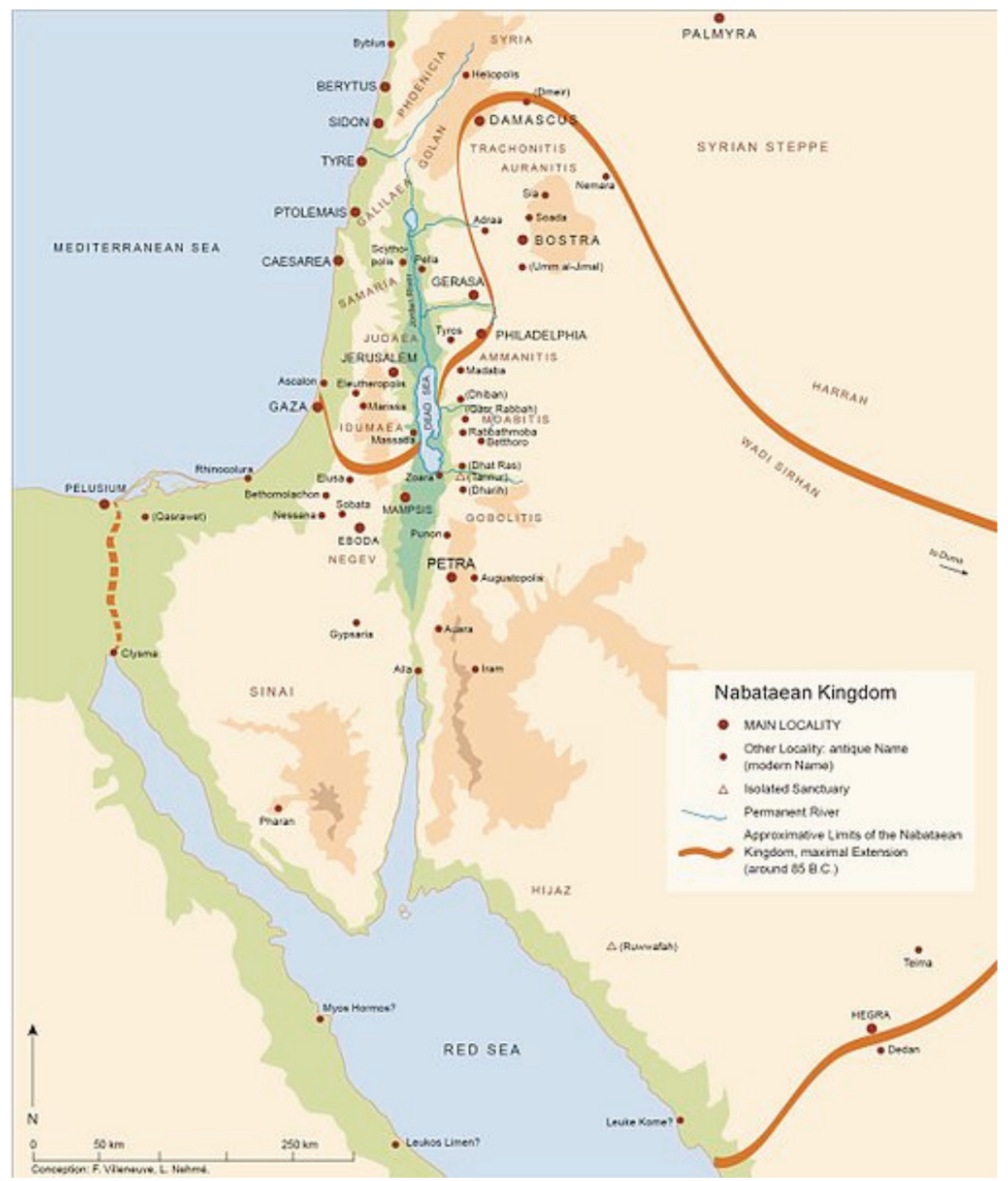

Fig. 1. Map of the Nabataean Kingdom

(https://upload.wikimedia.org/wikipedia/commons/0/00/Nabatean_Kingdom_map.jpg) 
the museums mentioned above, this excavation increased the destruction of the temple and the site in general.

Because of this, the need for further research has arisen. A comprehensive study, including a three-dimensional documentation, is needed for the site in general, related to all its architectural and sculptural remains, and/or for the collections housed in the museums mentioned above. These studies, and the documentation of the site's finds and ruins, can be prepared as educational material for the public in the form of hard and soft materials. Additionally, the 3D documentation of the Khirbet et-Tannur statues offers the opportunity to produce copies of these statues by specialized 3D printers and then return them to their original place at the Khirbet et-Tannur site. Longer-lasting materials can be used for the replicas. This technique is particularly useful in the Khirbet et-Tannur case because of the impossibility of reinstating the original statues in Jordan that are currently housed in the Cincinnati Art Museum.

The conservation, restoration, and reconstruction of the site with its sculptural features will return one of the most important historic and touristic Nabataean sites to Jordan. This isolated temple on a hilltop makes it a unique touristic experience. From a historical perspective, it adds important details to the story of the Nabataeans in Jordan.

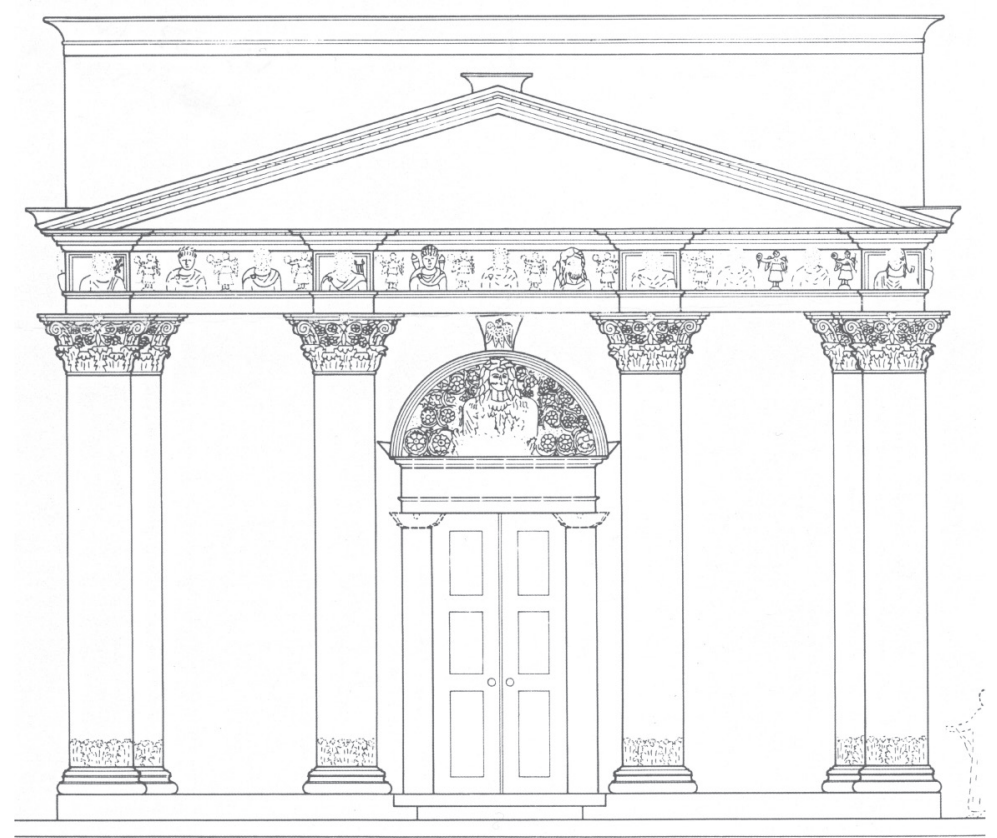

Fig. 2. Elevation of the façade of the inner temple enclosure, with the Atargatis Panel above the entrance ${ }^{2}$

${ }^{2}$ MCKenzIE, J.: Carvings in the Desert: The Sculpture of Petra and Khirbet et-Tannur. In MarkOE, G. (ed.): Petra Rediscovered: Lost City of the Nabataeans. London 2003, 165-191, here Fig. 180. 


\section{ATARGATIS IN MYTHS AND HISTORY}

In Hammond's opinion, once settled on the land, the Nabataeans accepted the current Syro-Palestinian chief goddess into their own religious structure as a consort for their native deity, Dushares. Atargatis may have come to Petra via the trade route between Petra and southern Syria across the Hauran. By the time of this acceptance, Atargatis would have been the reigning fertility goddess throughout the area, surpassing all Semitic rivals. ${ }^{3}$ This goddess may have been worshiped by the Nabataeans by the name of Allat, the native Arab goddess, as Hammond agreed later in some of his research. ${ }^{4}$

It is worth mentioning that Atargatis was originally worshipped at Manbij in northern Syria, situated some $75 \mathrm{~km}$ north-east of Aleppo, where her temple still stands in the city. The city was called Hierapolis by the Greeks, while Atargatis was known as Derceto. ${ }^{5} \mathrm{~A}$ bas-relief sculpture in basalt, uncovered at Manbij or Hierapolis, depicts a High Priest worshipping Atargatis and her consort, Hadad. ${ }^{6}$

In the Roman period, the bronze coins which the city minted gave a very special place to the goddess to whom the community owed its identity. The coins were stamped on the obverse with the name of the Emperor and on the reverse with the Syrian Goddess of the Hieropolitans - in Graeco-Roman terms -, some coins showing the goddess seated on a throne, with a lion standing on either side. ${ }^{7}$

Covering the body of Atargatis with plant leaves as she gives birth connected and made her equal to earth as the main source of life. Some scholars still regard her as the natural cause which supplies from moisture the beginnings and seeds of everything, and points out to mankind the source of all blessings. ${ }^{8}$

In our opinion, the union of the goddess Atargatis and the god Baal Shamin in the Khirbet et-Tannur temple may go back in its origin to the sacred marriage known and practised in ancient Mesopotamia. ${ }^{9}$ When celebrating marriage at special occasions like the beginning of spring, a kind of fertility ritual was practiced by the Nabataeans, who gathered at this high place with its isolated temple to participate in these ceremonies.

\footnotetext{
${ }^{3}$ Hammond, PH. C.: The Nabataeans - Their History, Culture and Archaeology [Studies in Mediterranean Archaeology 37]. Gothenburg 1973, 96.

${ }^{4}$ Hammond, PH. C.: The Goddess of the Temple of the Winged Lions at Petra (Jordan). In ZaYADINE, F. (ed.): Petra and the Caravan Cities. Amman 1990, 123-124.

${ }^{5}$ Millar, F.: The Roman Near East 31 BC - AD 337. Cambridge, MA - London 1993, 242-243.

${ }^{6}$ Millar (n. 5) 245.

${ }^{7}$ Millar (n. 5) 243.

${ }^{8}$ Millar (n. 5) 245.

${ }^{9}$ VAN BUREN, E. D.: The Sacred Marriage in Early Times in Mesopotamia. Orientalia N. S. 13 (1944) $1-72$.
} 


\section{REPRESENTATIONS OF ATARGATIS IN ARAB CENTERS}

\subsection{Hatra in Iraq}

Impressive representations of Atargatis in the round and in relief have been uncovered in Hatra in Iraq. The relief, called the Nergal Panel (Fig. 3), features the god of war and the underworld, with Atargatis depicted in the top right corner, enthroned upon two lions with an eagle above her head. The symbolism and jewelry recall to the mind the Khirbet et-Tannur high relief statue of Atargatis in different aspects (Fig. 9): the throne of lions, the eagle above the head, and the wearing of a necklace.

While the second statue was done in the round, it is the upper part of Atargatis which seems to be sitting on a throne (Fig. 4), with her crown above her head and a scepter in her right hand. She is wearing a necklace as yet another sign of divinity. An eagle is standing on her left on the arm of the throne.

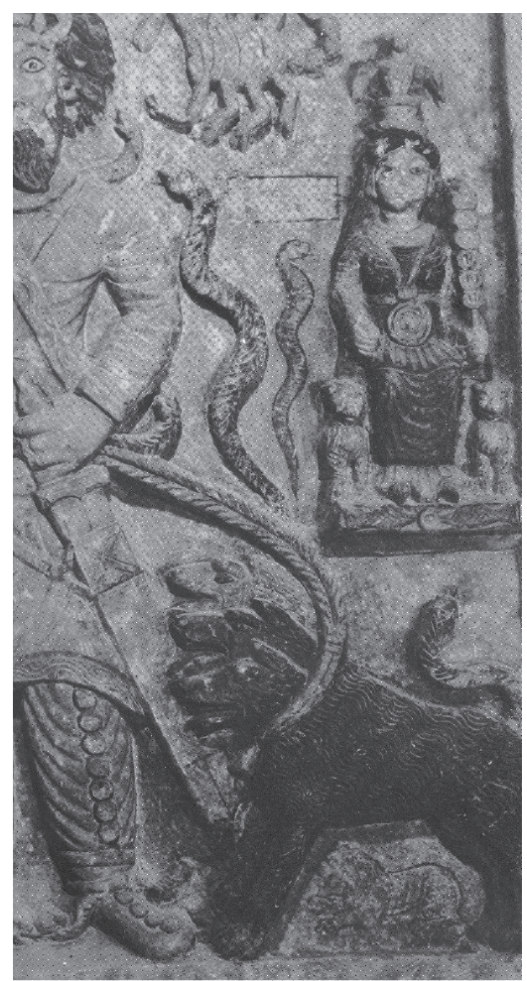

Fig. 3. A relief Panel of Nergal and Atargatis, Hatra ${ }^{10}$

${ }^{10}$ SAfar, F. - Mustafa, M.: Hatra, the City of the Sun God. Baghdad 1974, 190. 


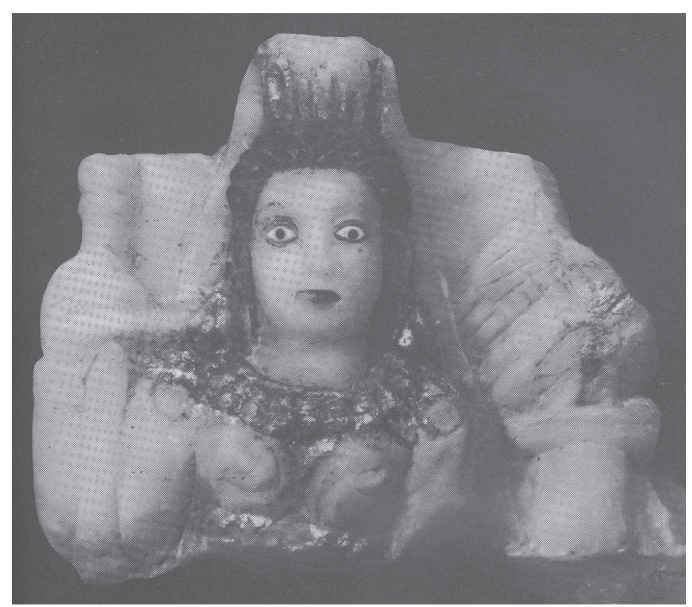

Fig. 4. Bust of Atargatis, Hatra ${ }^{11}$

\subsection{Dura-Europos in Syria}

Atargatis, as represented in this site, is quite distinct from her representation in the Panel at the Temple of Atargatis. Dated between 100-256 AD, she appears enthroned with two lions beside the god named Hadad, usually shown enthroned on two bulls (Fig. 6). ${ }^{12}$ This relief is very close to the one found at the Khirbet et-Tannur Temple (Figs 7 and 9).

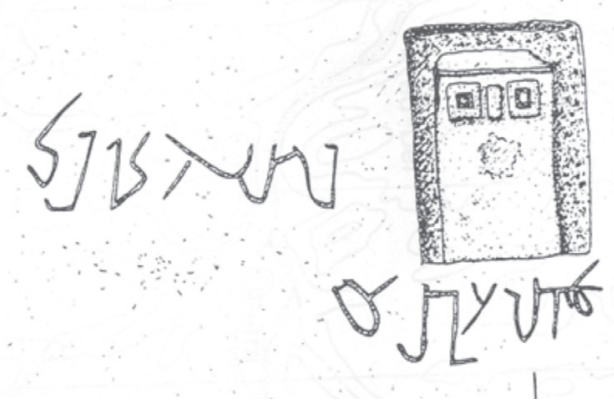

Fig. 5. A baityl and an inscription of Atargatis, Siyyag Gorge, Petra ${ }^{13}$

\footnotetext{
${ }^{11}$ SAFAR-MUSTAFA (n. 10) 175.

${ }^{12}$ Millar (n. 5) 245.
}

${ }^{13}$ Lindner, M. - Zangenberg, J.: The Re-Discovered Baityl of the Goddess Atargatis in the Șiyyag Gorge of Petra (Jordan) and Its Significance for Religious Life in Nabataea. In Zeitschrift des Deutschen Palästina-Vereins 109.2 (1993) 141-151, here Fig. 1. 


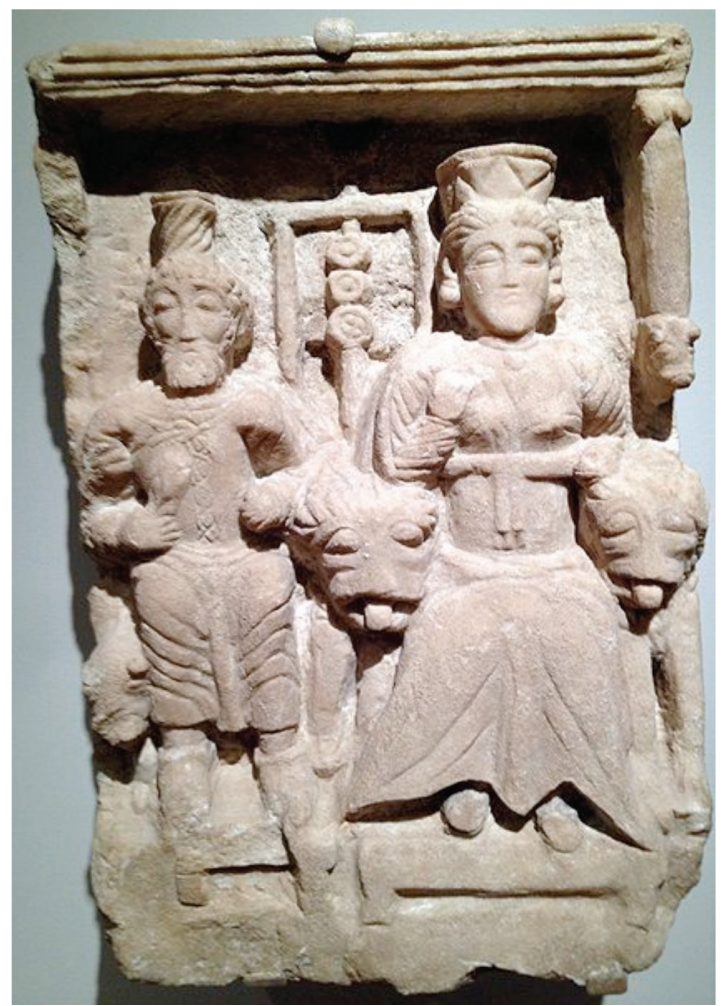

Fig. 6. Relief of Atargatis enthroned with two lions (on the right) beside the god Hadad, Dura-Europos (https://s-media-cache- ak0.pinimg.com/originals/7c/a4/d4/7ca4d4611d6eaca1802205e022df1fe7.jpg)

\section{ATARGATIS IN THE NABATAEAN KINGDOM}

The worship of Atargatis by the Nabataeans is not a source of debate among scholars. A baityl and an inscription of Atargatis' name have been discovered in the Siyyag Gorge of Petra (Fig. 5). An idol carved in the baityl, with eyes and nose in the upper quarter of the rectangle is indicated by square frames with pupil holes in the centres. The nose is indicated by a vertical band. The baityl is identified by an inscription translated as Atargatis of Manbidj (Fig. 5). ${ }^{14}$ From this baityl and the inscription, two conclusions can be drawn. Firstly, that the idol is carved in an abstract style, the original style adapted by the Nabataeans. This may mean that they worshiped Atargatis from the early times of their kingdom to the late periods. Secondly, the connection of the idol and the inscription is not in doubt, and the mention of Atargatis' name in the Nabataean inscription clearly points to the fact that this goddess played an important role in Nabataean religion, not only in their capital Petra, but also in other places throughout their kingdom.

${ }^{14}$ LindNER-ZANGENBERG (n. 13) Fig. 1. 
Therefore, it is not surprising that several temples and other sanctuaries along the important route from Petra to the north into Syria and Mesopotamia were also dedicated to Atargatis, such as Hauran, es-Suweda and Gebel ed-Druz. ${ }^{15}$

One of these sites is Khirbet et-Tannur. The iconography at this site demonstrates that Atargatis was the goddess related to fertility. From this Nabataean starting point, she went on to assume the features and personalities of other contenders for the role of the general fertility-goddess. ${ }^{16}$

The cult statues found by Glueck at the Khirbet et-Tannur Temple suggest that this temple was dedicated to the worship of the god Baal Shamin (the lord of heaven) and his consort, the goddess Atargatis. One of these statues is made of sandstone and represents a male with a female (Figs 7 and 9). The male is in the form of Hadad, the god of storm, thunderbolt and rain identified by a thunderbolt mace held in his left hand and the bull statues on either side of him (Fig. 7). This god may have been worshipped by the Nabataeans under the name Qaws, as mentioned in one of the inscriptions found at the site (Fig. 8). Originally, he was seen as the Adomite god, Baal Shamin or Dushara (the lord of Nabataean deities). The female depicted as his consort, Atargatis (al-Uzza in Petra or Allat elsewhere), ${ }^{17}$ is identified by her guardian lions on either side of her statue (Figs 9 and 10). Both Baal Shamin and Atargatis are depicted with twisted torques with lion heads around their necks. ${ }^{18}$

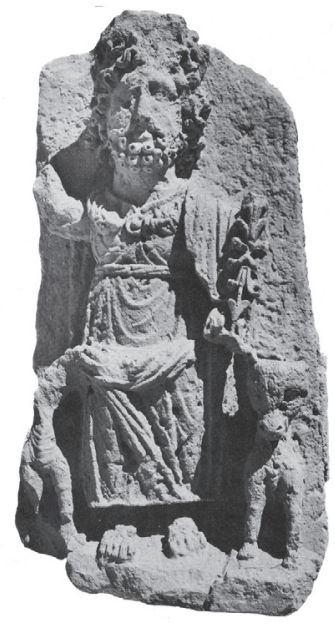

Fig. 7. High relief statue of Baal Shamin, et-Tannur site ${ }^{19}$

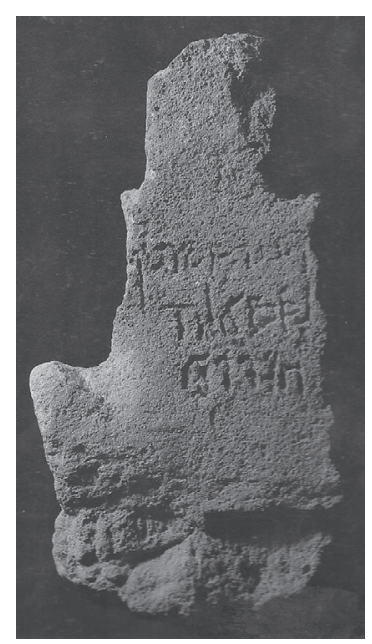

Fig. 8. An inscription of the name of god Qaws, et-Tannur site ${ }^{20}$

${ }^{15}$ LINDNER-ZANGENBERG (n. 13).

${ }^{16}$ HAMMOND: The Nabataeans (n. 3) 96-97.

${ }^{17}$ MCKenZIE: Carvings (n. 2) 186.

${ }^{18}$ Glueck, N.: Deities and Dolphins: The Story of the Nabataeans. New York 1965, 265-284; AlmaSRI, E. - AlaWNeH, F. - BALA'WI, F.: Nabataean Jewellery and Accessories. Ancient Near Eastern Studies (University of Melbourne) 49 (2012) 150-175.

${ }^{19}$ GLUECK: Deities (n. 18) 94.

${ }^{20}$ GLUECK: Deities (n. 18) 438. 


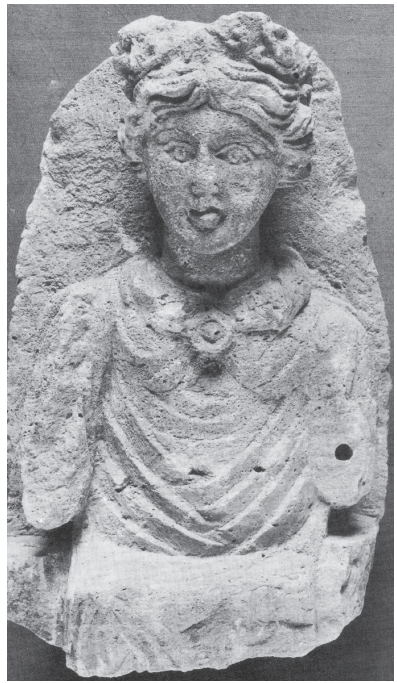

Fig. 9. High relief statue of Atargatis, et-Tannur site ${ }^{21}$

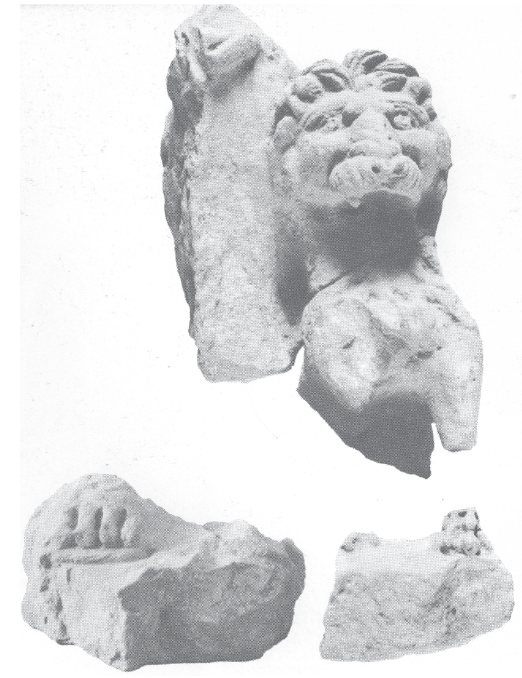

Fig. 10. High relief of a lion, guard of Atargatis ${ }^{22}$

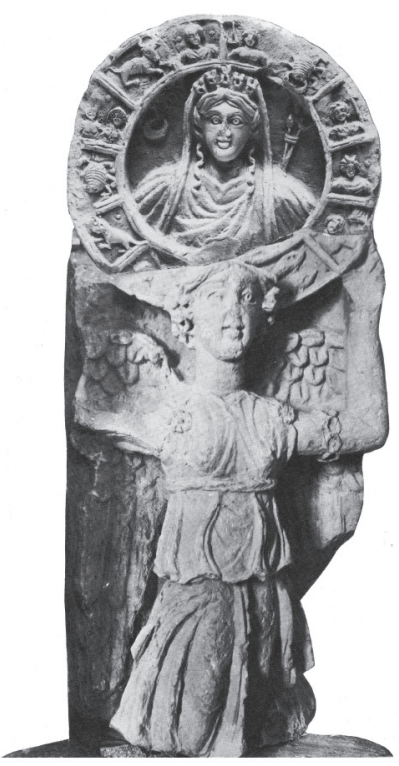

Fig. 11. High relief statue of the goddess Nike holding the zodiac encircling the goddess Tyche ${ }^{23}$

${ }^{21}$ GLUECK: Deities (n. 18) 96.

22 GLUECK: Deities (n. 18) 363.

${ }^{23}$ GLUECK: Deities (n. 18) 110. 
In Glueck's opinion, Atargatis assumed many forms, and played many roles in this site, as a grain or wheat goddess (Fig. 13), a vegetation goddess (Fig. 14), a guardian goddess, (Figs 9 and 14), a fish goddess (Fig. 12), and a zodiac goddess. ${ }^{24}$ All these statues and roles are connected in one way or another with the Syrian goddess Atargatis, the Egyptian goddess Isis, ${ }^{25}$ and Allat, ${ }^{26}$ the Arabian goddess, as a fertility goddess, shown here as a chief among the gods in the temple and in Nabataean religion.

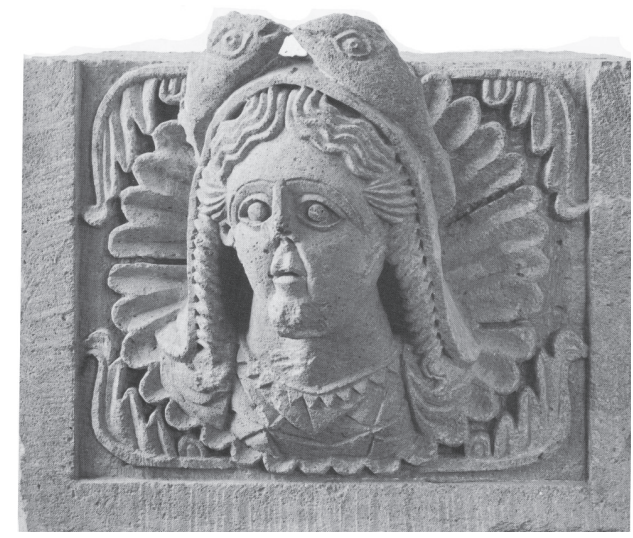

Fig. 12. High relief statue of Atargatis as a fish goddess, et-Tannur site ${ }^{27}$

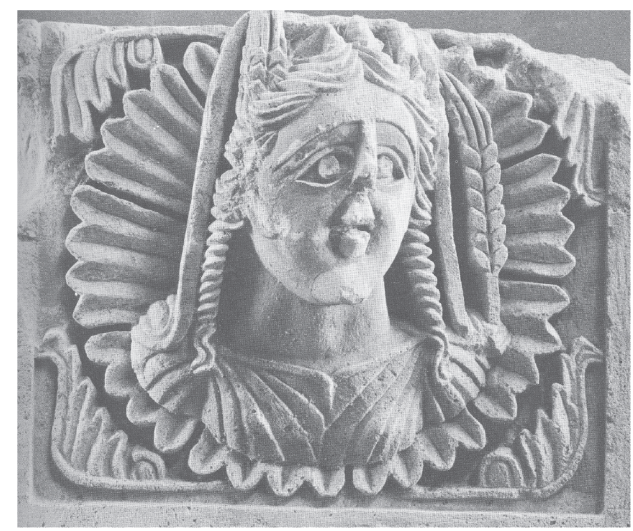

Fig. 13. High relief statue of Atargatis as a grain goddess, et-Tannur site ${ }^{28}$

In addition to the statues from the et-Tannur site, a relief of the head of Atargatis was found in the Temenos of Qasr El-Bint at Petra. ${ }^{29} \mathrm{~A}$ wide array of terracotta figurines were discovered in the Petra region depicting

Atargatis. ${ }^{30}$ Atargatis appeared nude in some of these figurines, raising her right hand in the gesture of

blessing and ornamented with different types of jewelry. The nudity may reflect her role in fertility.

${ }^{24}$ GLUECK: Deities (n. 18) 472.

${ }^{25}$ LYTTELTON, M.: Aspects of the Iconography of the Sculptural Decoration of the Khazneh at Petra. In Zayadine, F. (ed.): Petra and the Caravan Cities. Amman 1990, 19-29.

${ }^{26}$ MiLIK, J.: Origines des Nabateens. In Studies in the History and Archaeology of Jordan I. Ed. by A. HADIDI. Amman 1982, 261-265, here 262.

${ }^{27}$ GLUECK: Deities (n. 18) 13. 


\section{THE ATARGATIS PANEL (CASE STUDY)}

\subsection{Origin and Discovery}

The so-called Atargatis Panel (Figs 2, 14, 15 and 16) was found in the collapsed facade of the Khirbet et-Tannur Temple. It was discovered during the excavations of the site in 1937, under the direction of Nelson Glueck (Fig. 15). ${ }^{31}$

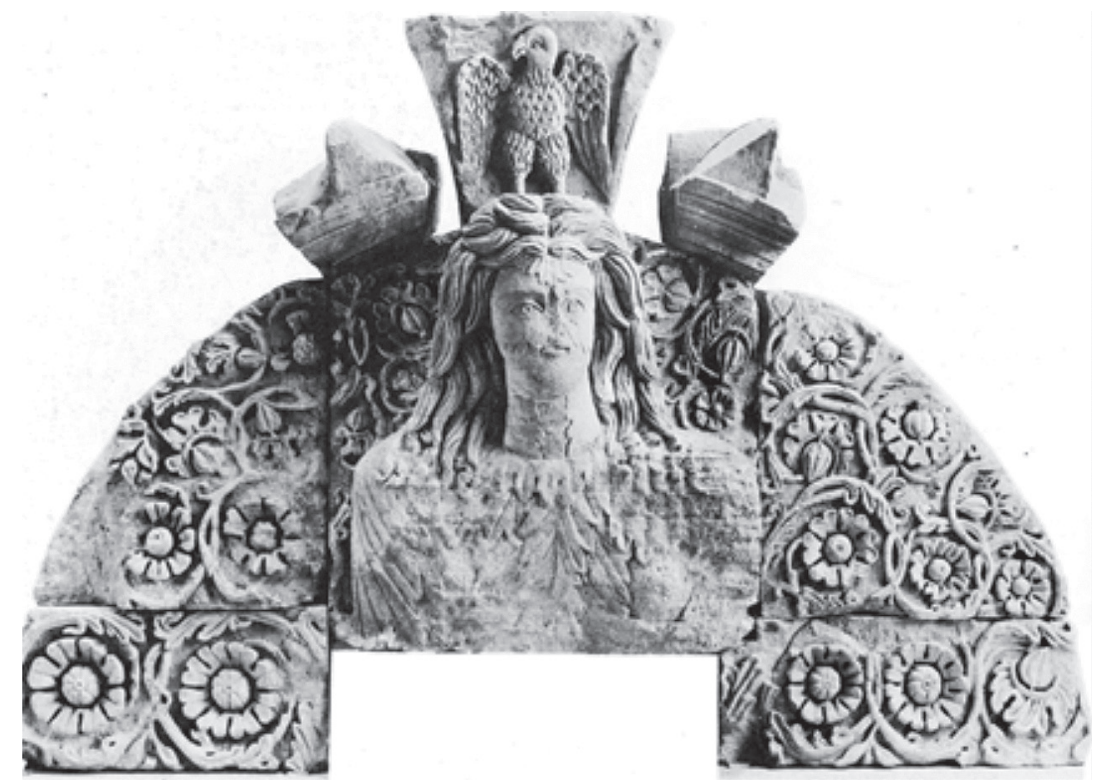

Fig. 14. The Atargatis Panel ${ }^{32}$

${ }^{28}$ GLUECK: Deities (n. 18) 49.

${ }^{29}$ Lyttelton, M. - BlagG, T.: Sculpture from the Temenos of Qasr El-Bint at Petra. ARAM 2 (1990) 267-286, here Pl. 9.

${ }^{30}$ Horsfield, G. - Conway, A.: Sela-Petra, the Rock, of Edom and Nabatene. The Quarterly of the Department of Antiquities in Palestine 9 (1942) 105-204, here 161, Pl. XXX, 257, 258; PARR, P.: A Commentary of the Terracotta from the British Excavations at Petra 1958-64. In ZaYADINE, F. (ed.): Petra and the Caravan Cities. Amman 1990, 77-86, here 85, Figs. 3 and 5; PARLASCA, I.: Terrakotten aus Petra, ein neues Kapitel nabatäischer Archäologie. In ZAYADINE, F. (ed.): Petra and the Caravan Cities. Amman 1990, 87-106, here Taf. 1. 1,2; SCHMITT-KorTE, K.: Die Nabatäer. Spuren einer arabischen Kultur der Antike. Ein Begleiter durch die archäologische Ausstellung im Kestner-Museum Hannover 28.11.1976 - 30.01.1977. Hannover 1976, Pl. 26.

${ }^{31}$ GLUECK, N.: A Newly Discovered Nabataean Temple of Atargatis and Hadad at Khirbet et-Tannur, Transjordan. American Journal of Archaeology 41 (1937) 361-376; GLUECK: Deities (n. 18); MCKENZIE ET AL. (n. 1) 67-68.

${ }^{32}$ GLUECK: Deities (n. 18) Pl. 32. 


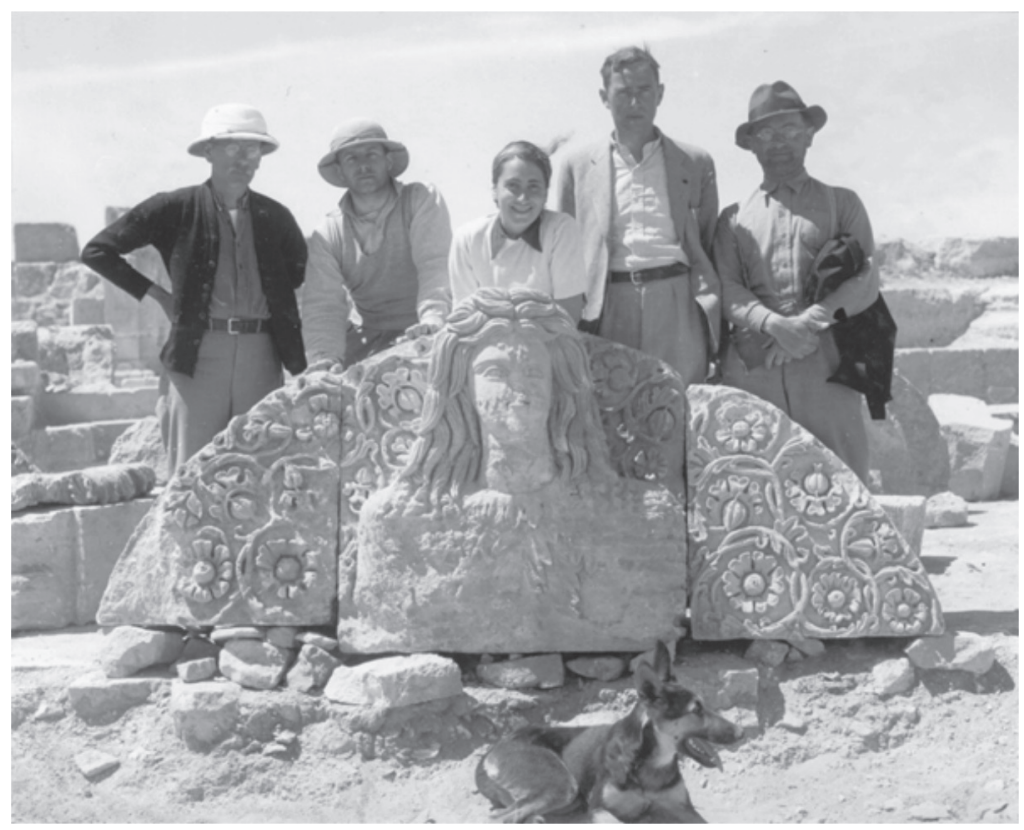

Fig. 15. Glueck (the second from the right) and others at the et-Tannur site, behind the Atargatis Panel (http://asorblog.org/2013/10/15/atarah-in-the-archives-nelson-gluecks-canine-companion/)

\subsection{The Khirbet et-Tannur Temple}

Khirbet et-Tannur is a small Nabataean temple, dating from the later part of the 2nd century BC. The completely isolated hill of the Tannur mount stands above the Wadi el-Hasa on the Kings' Highway, near Khirbet edh-Dharih. This served as the third caravan stop, $70 \mathrm{~km}$ north of the Nabataean capital, Petra (Fig. 1). Caravaneers stopped here with the intention of securing the fertility of their animals, gaining protection from evil, and fostering their commercial success. ${ }^{33}$ In Glueck's opinion it was a religious centre. There was no particular village or town here, nor was it close to any crossroad. Despite this, it was likely regarded as a sacred spot for the general public and as an important place for pilgrimage. It belonged to the kingdom, as a whole. ${ }^{34}$

\subsection{The Recent Site}

After a long period of time, during which the Atargatis Statue was on display at The Amman Citadel Museum (Fig. 16), the statue was recently moved by the Department of Antiquities of Jordan to The Jordan Museum (Figs 17a, b and c) in downtown Amman,

\footnotetext{
${ }^{33}$ LINDNER-ZANGENBERG (n. 13) 149.

${ }^{34}$ GLUECK: Deities (n. 18) 77.
} 
where it is now on display in the entrance hall of the museum, registered under two numbers, as J 3258 by the Department of Antiquities and as JMA 1526 by The Jordan Museum.

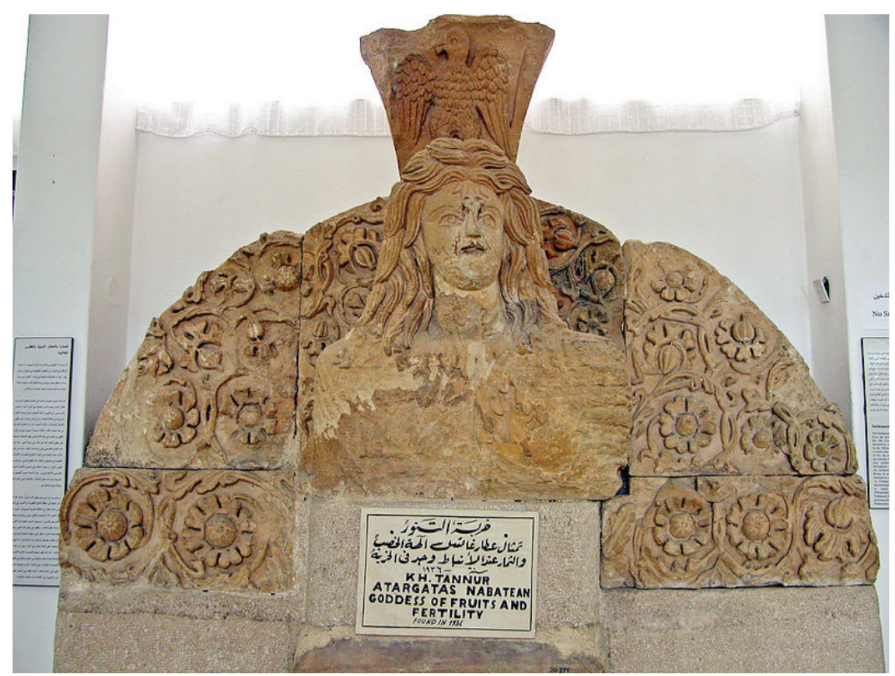

Fig. 16. The Atargatis Panel displayed at The Amman Citadel Museum (https://upload.wikimedia.org/wikipedia/commons/8/8c/

Atargatis\%2C_Nabatean\%2C_c.100_AD\%2C_Jordan_Archaeological_Museum.jpg)

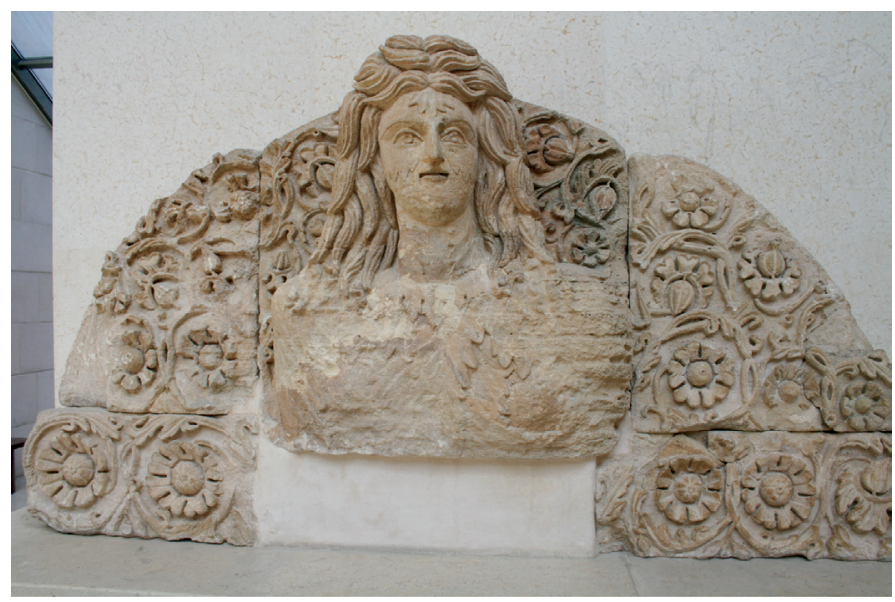

Fig. 17a 


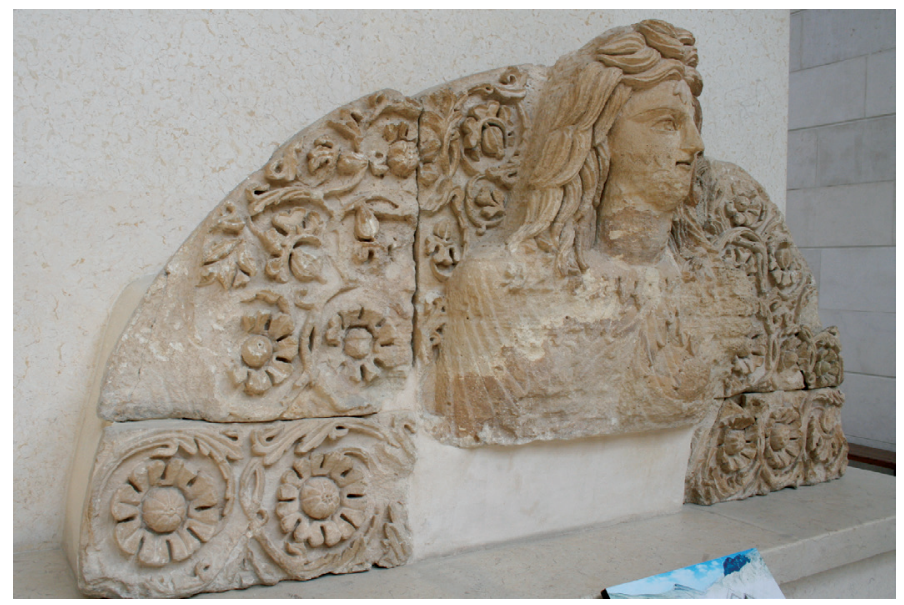

Fig. 17b

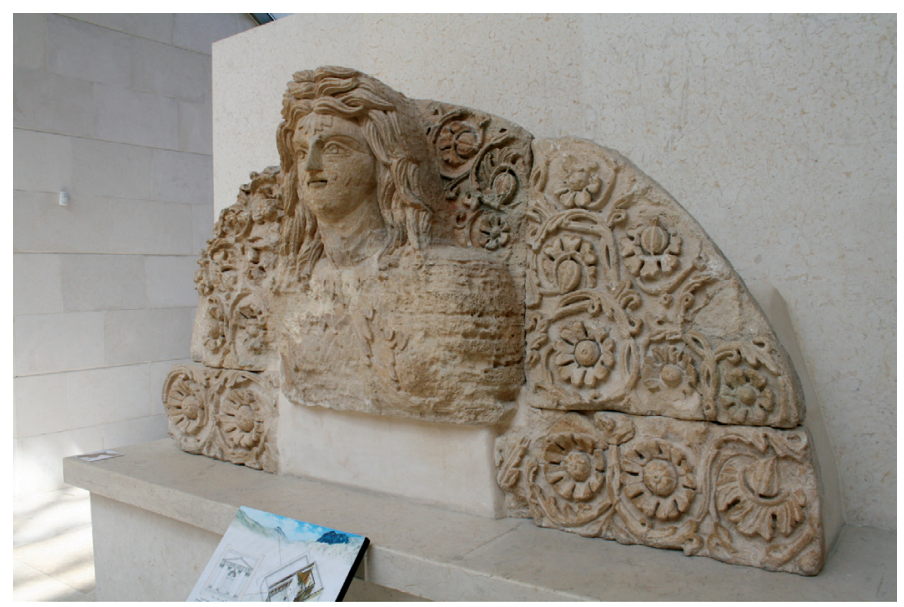

Fig. 17c

Fig. 17. The Atargatis Panel displayed at The Jordan Museum in downtown Amman

\subsection{Description of the Statue}

The high relief statue of Atargatis is made of limestone. It is a semi-circular panel depicting the bust of a veiled goddess, featured larger than life, rising from a massive block. Her face, neck and body were covered with vine leaves, leaving her breasts bare. Her hair is parted in the middle and styled into carefully separated tresses, framing her face and falling over the front of her shoulders. On each side of her head, the top of which rises above the radius of the Panel and extends to four connecting sections, there can be found an intricate pattern of interlaced vines and acanthus leaves encircling sep- 
arate rosettes, figs and pomegranates. It was originally placed above the doorway in the inner temple-court. It had a simple cornice around it with an acroterion at either end. Above the panel, there was an acroterion with an eagle carved on its front ${ }^{35}$ (Figs 2, 14 and 15).

The floral scroll background, from which her high relief emerges, consists of an intricate bower of interwoven vines encircling formalized acanthus leaves, completely or partly open rosettes of various sizes possessing eight or less double petals. Pomegranates or figs appear in the composition. An eagle with extended wings can be seen above her head. ${ }^{36}$

\subsection{The Art Style}

Nabataean sculpture, in general, is divided into three main groups. The first one is the non-figurative group, ${ }^{37}$ referred to as the Abstraction or Cubism style. This includes what is sometimes referred to by scholars as eye idols or betyls or stelae; it is generally a form of relief found in rectangular stone blocks, with few round blocks found. The Nabataeans carved the statues of their deities in this style because they believed that nothing looked like the god. This style was widespread in the southern part of the Nabataean Kingdom, particularly in Petra, concentrated mainly on the Siq (the main entrance of the city), in Hegra (Mada'in Saleh) and in Wadi Rum.

The second group is figurative, with Greek influence and Oriental features, similar to the group of statues from Khirbat Al-Tannur. This second group can be classified as belonging to the Realistic style because it includes Hellenistic influence with local elements. This style reflects common features of sculpture in the Nabataean Kingdom and other Arab centres, like Palmyra in Syria and Hatra in Iraq. It also exhibits some sculptural elements from the Moabite and Ammonite kingdoms, both of whom inhabited Jordan before the Nabataeans.

The third group is of Greek and Roman influence, including some of the statues found at Petra and on the façade of the Treasury. These can be referred to as Classical in style because they reflect features of the Classical Period, around the $4^{\text {th }}$ century BC.

The Atargatis statue can be classified as belonging to the second group, the figurative or local Hellenistic style. In this style, the Nabataean sculptor did not pay attention to proportions, human anatomy, the movement of the body, details, or even texture.

Instead, this style is characterized by the rigidity of the body and clothes folds, silent facial expression, bulky face, prominent eyes, raised pupils, with the two sides

35 GLUECK: Deities (n. 18) 143, 289, 290; MCKenZIE, J.: The Development of Nabataean Sculpture at Petra and Khirbet Tannur. Palestine Exploration Quarterly 120 (1988) 81-107; MCKENZIE: Carvings (n. 2) 175 .

${ }^{36}$ GLUECK: Deities (n. 18) 289.

${ }^{37}$ PATRICH, J.: The Formation of Nabatean Art: Prohibition of a Graven Image among the Nabateans. Jerusalem 1990; PATRICH, J.: Prohibition of a Graven Image among the Nabataeans. The Evidence and Its Significance. ARAM 2 (1990) 185-196. 
of the statue being identical, along with the extensive use of decorations, symbols and ornaments.

It is worth mentioning here that the raised pupils are characteristic of the Nabataean style and notably, this appears clearly in the Atargatis statue.

\subsection{Symbols Featured in the Atargatis Panel}

Acanthus leaves: Extensively used in sculpture and decoration as stylised ornamental motifs; often the leafy ornament used in capitals of Corinthian columns. ${ }^{38}$ It was a very common plant in the Mediterranean region in spring time, so it can be interpreted as a sign of renovation and rebirth.

Bare breasts: Covering the body, part of the face, the neck and the rest of Atargatis' bust with acanthus leaves (Figs 17a, b and c) while leaving the breasts uncovered, makes it the visual focal point and the entire focus in terms of its meaning. It directs the attention to this sacred source of giving and ensuring life.

The depiction of Atargatis as a mother goddess, along with the uncovering of a vast number of figurine statues and nude images of other mother goddesses, further demonstrates the widespread practice by prehistoric societies throughout this region, of the worship of mother goddesses.

Fig: It can be seen on the upper part of the Panel behind Atargatis' figure (Figs $17 \mathrm{a}, \mathrm{b}$ and $\mathrm{c}$ ). It serves to underscore the phenomenon of birth and ripening. ${ }^{39}$ It was a sign of peace and prosperity. ${ }^{40}$ In addition to that, and because the fig tree lasts for a long time, it can be viewed as a sign of life and immortality. And finally, the presence of an abundance of seeds inside the fig fruit can be seen as a symbol of fertility.

Pomegranate: It can be seen inside rosettes on the lower part of the panel on either side of Atargatis' figure (Figs 17a, b and c). It has long been considered as a symbol of fertility as reflected in the abundance of its seeds. It was viewed both in the east and the west as a regenerative fruit from the tree of life. ${ }^{41}$ In addition to its abundance of seeds, its symbolism comes also from its shape and internal structure; it brings many to one. It can be said that the entire universe was born from one goddess, and she is Atargatis, the source of life.

Rosette: It can be seen with a pomegranate fruit inside it on either side of Atargatis' figure (Figs 17a, b and c). The rose is sacred to goddesses everywhere, and was particularly adopted by the prostitute priestesses of Venus in Roman times. ${ }^{42}$ Because it is associated with the spring season, it symbolises regeneration and rebirth.

Vine leaf: It can be seen carved on the Panel on either side of Atargatis' figure, encircling the pomegranate and fig fruits (Figs 17a, b and c). The most popular rep-

\footnotetext{
${ }^{38}$ STEWART, W.: Dictionary of Images and Symbols in Counselling. London-Philadelphia 1998, 19.

${ }^{39}$ GLUECK: Deities (n. 18) 291.

${ }^{40}$ STEWART (n. 38) 166.

${ }^{41}$ GLUECK: Deities (n. 18) 289-290.

${ }^{42}$ STEWART (n. 38) 366.
} 
resentation of life, ${ }^{43}$ and from its interlaced and circular shape, vines are considered to be a symbol of eternal life.

The extensive use of these symbols in the Atargatis statue reflects a variety of religious concepts. Not only is the fertility aspect of the goddess highlighted, but there is also clear reference to the concepts of after-life, revival and protection. Furthermore, the appearance of other symbols in other Atargatis statues found at the site, like the zodiac, reveal the cosmic power of the goddess and her relationship to time, seasons and the future of humans.

\section{THE 3D DIGITAL DOCUMENTATION OF ATARGATIS}

The need to provide high quality 3D modelling of the heritage sites and objects has stimulated further research in the field of photogrammetry and computer vision. ${ }^{44}$ Photogrammetry is based on a 3D data collection from multiple images. The geometry is created by identifying sets of common points from two or more source images. The topological relationship between those points has to be taken into consideration to form the edges and the surfaces of the object. These images not only provide geometric information but also show the surface texture of the depicted objects. This is especially important while aiming at the production of 3D virtual models.

A number of traditional photogrammetric approaches use point matches, which allow for direct solutions based on three, four or six corresponding points. Recently, improvements in photogrammetric matching algorithms have come to allow for an automatic production of dense 3D point clouds. The algorithms apply the principles of standard photogrammetry but with full automation process in matching the images in wise pixel resolution. ${ }^{45}$ The point cloud might typically contain between one and ten billion points that describe the building surfaces inside and out, with accurate modelling up to sub-millimetres. ${ }^{46}$

The presented work applies the dense matching technique to create a reliable 3D modelling of the Atargatis statue at The Jordan Museum. The dense matching technique can produce a dense $3 \mathrm{D}$ point-cloud data that is required to create high-resolution geometric models. Rothermel and others ${ }^{47}$ presented the new multi-view stereo (MVS)

${ }^{43}$ STEWART (n. 38) 378.

${ }^{44}$ Dellepiane, M. ET Al.: Archeological Excavation Monitoring Using Dense Stereo Matching Techniques. Journal of Cultural Heritage 14.3 (2013) 201-210.

${ }^{45}$ DetcheV, I. - HABIB, A. - El- BADRY, M.: Dynamic Beam Deformation Measurements with Off-the-shelf Digital Cameras. Journal of Applied Geodesy 7 (2013) 147-157. doi:10.1515/jag-2012-0052; REmondino, R. ET AL.: Dense Image Matching: Comparisons and Analyses. Digital Heritage 1 (2013) 47-54.

${ }^{46}$ CEFAlU, M. ET AL.: Image Based 3D Reconstruction in Cultural Heritage Preservation. Institute for Photogrammetry, University of Stuttgart 2013; GRUSSENMEYER, P. ET AL.: Recording Approach of Heritage Sites Based on Merging Point Clouds from High Resolution Photogrammetry and Terrestrial Laser Scanning. In ISPRS - International Archives of the Photogrammetry, Remote Sensing and Spatial Information Sciences. Volume XXXIX-B5 (2012) 553-558.

${ }^{47}$ Rothermel, M. ET AL.: SURE: Photogrammetric Surface Reconstruction from Imagery. Proceedings LCD Workshop, Berlin, December 2012. 
method in order to generate dense and precise 3D point clouds. The implementation is based on the Semi-Global Matching algorithm developed by Hirschmüller, ${ }^{48}$ followed by a fusion step to merge the redundant depth estimation across single stereo models. In order to reduce the time and memory, a hierarchical coarse to fine algorithm was used to derive search ranges for each pixel individually. The developed dense image matching algorithm was implemented by the software called SURE.

In our approach, sparse correspondences were the initial stages of the matching developments in order to find the orientation parameters of the camera and the images collected for the surface. We have used the software Visual SFM developed by Wu. ${ }^{49}$ The software improves the efficiency of the structure-for-motion matching algorithm by introducing a preemptive feature matching that provides a good balance between speed and accuracy.

Fig. 18 depicts the images collected from different angles achieving the required overlapping. The images used were taken with a Canon 400D calibrated camera with 12 mega pixels. Fig. 19 shows the position and orientation of the images reconstructed using the structure for motion algorithm. In addition to the camera parameters, sparse point clouds for the surface features can also be extracted.

In the final stage, the camera parameters are then passed through the dense image matching software SURE. The software algorithm is used for producing points for each overlapping pixel. The final 3D coloured point of the statue is shown in Fig. 20.

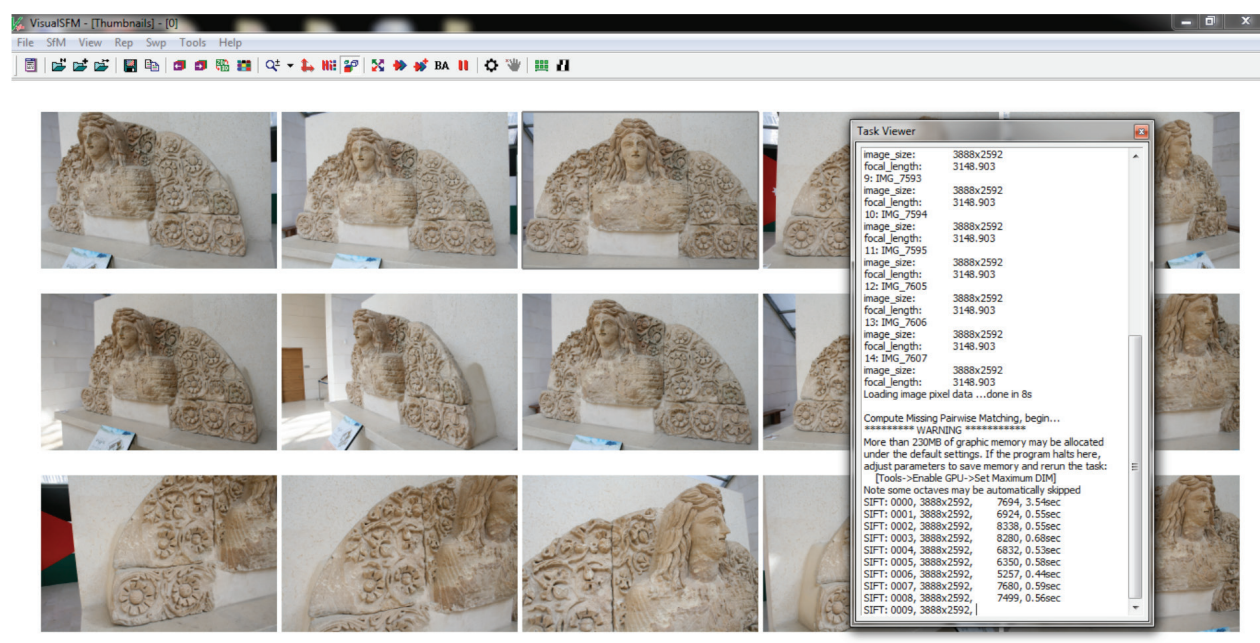

Fig. 18. Overlapped high resolution images used for modelling the Atargatis Statue

\footnotetext{
${ }^{48}$ HirschmülleR, H.: Stereo Processing by Semi-Global Matching and Mutual Information. IEEE Transactions on Pattern Analysis and Machine Intelligence 30.2 (2008) 328-341.

${ }^{49}$ Wu, C.: VisualSFM: A Visual Structure from Motion System. 2011. http://ccwu.me/vsfm/
} 


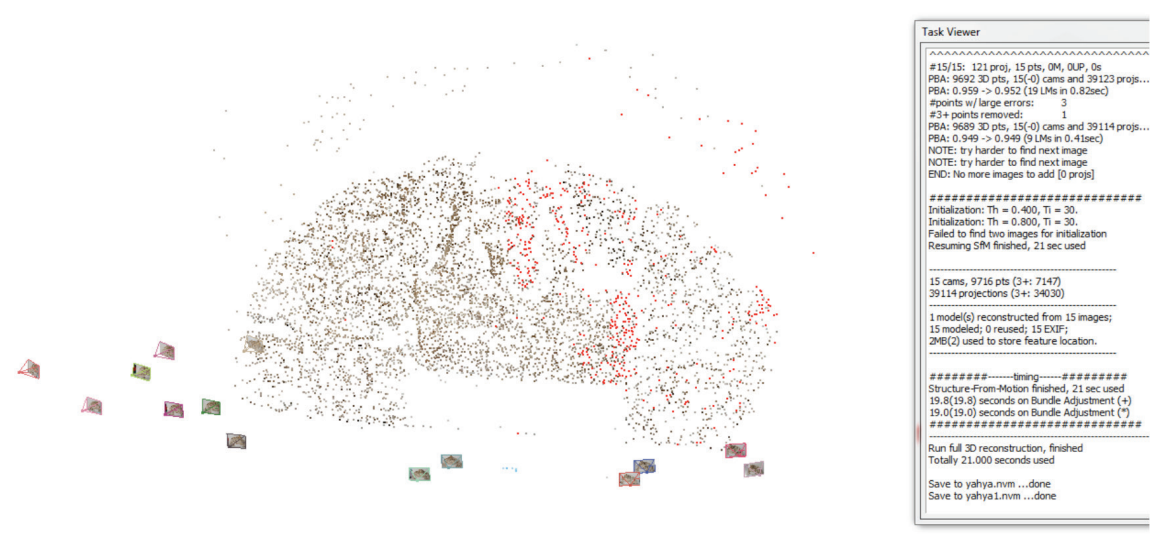

Fig. 19. Reconstruction of the image positions and orientation parameters using the structure for motion algorithm

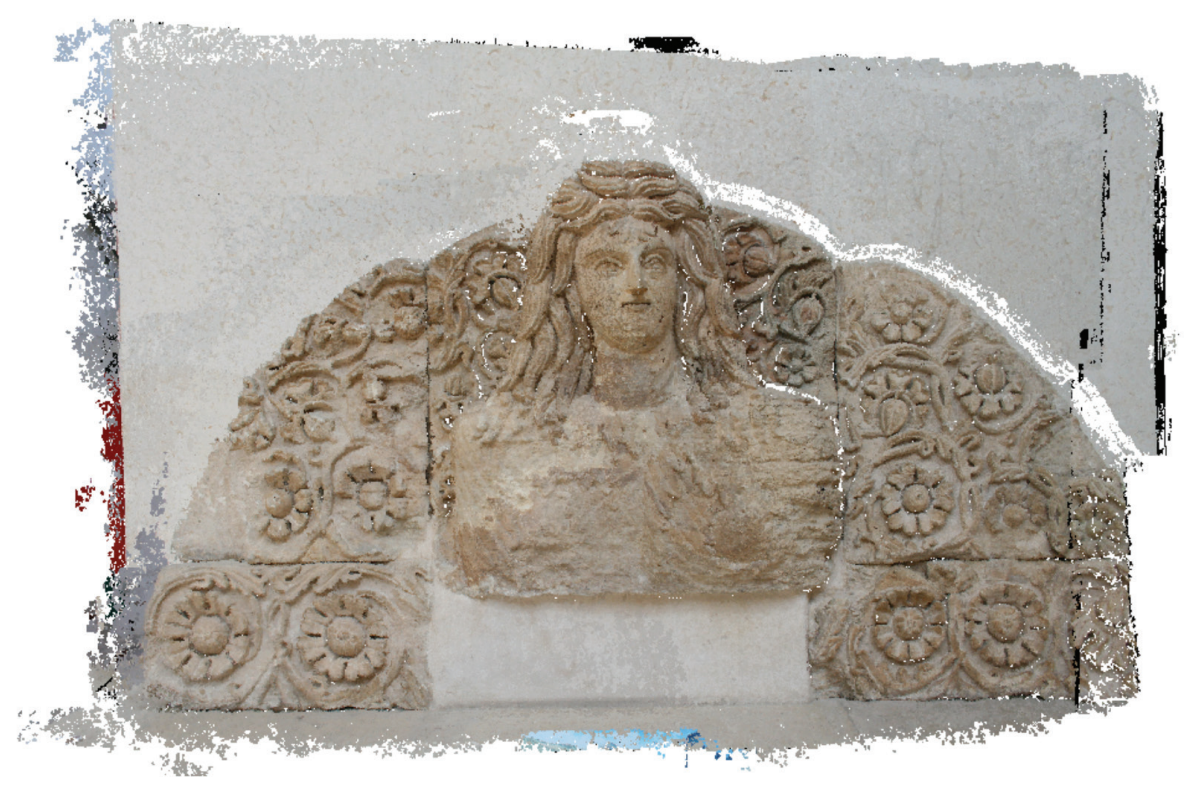

Fig. 20. 3D point clouds of the Atargatis Statue using DSM 


\section{CONCLUSION}

Atargatis played an important role in the religious life of the Nabataeans, not only in their capital Petra, but also in other places throughout their kingdom. A large number of evidences have been uncovered, such as an idol carved in the baityl and an inscription of Atargatis' name have been discovered in Petra. Several temples and other sanctuaries along the important route from Petra to the north into Syria and Mesopotamia were also dedicated to Atargatis, such as Hauran, es-Suweda and Gebel ed-Druz.

One of these temples is Khirber et-Tannur, dedicated to the worship of Atargatis with her consort, the god Baal Shamin. A wide number of Atargatis statues have been found in the site, representing her roles as a grain or wheat goddess, a vegetation goddess, a guardian goddess, a fish goddess, and a zodiac goddess.

Highly realistic geometric models of historical objects are a fundamental prerequisite for reconstruction or restoration purposes. 3D models allow the visualization of a structure from different angles for historical studies, archaeological research as well as virtual tourism. The paper discusses the modelling of the Atargatis statue at The Jordan Museum using image stereo matching algorithms. Acquiring 3D point clouds using images has many advantages related to flexibility and portability.

The documentation of the sculptural and architectural remains at the Khirbet et-Tannur Temple can help in the future conservation, restoration, and reconstruction of the site. The digital documentation of the current case study will offer further information about the Nabataeans in the region and also revive one of the most important Nabataean archaeological and touristic sites in Jordan.

Eyad Almasri - Fadi Balaawi - Yahya Alshawabkeh

Hashemite University

Queen Rania Faculty of Tourism and Heritage

Zarqa, Jordan

eyad@hu.edu.jo 